\title{
Evaluation of Color Properties of Wool Fabrics Dyed with Calligonum comosum at Different Dye Conditions
}

\author{
Dalia. M. Essa 1,* iD , Hoda Hussein ${ }^{1}$, Manal T.H Moselhy ${ }^{2}$ \\ 1 Textile Metrology Lab., National Institute for Standards, Giza, Egypt \\ 2 Al-Safwa High Institute of engineering, Cairo - Egypt \\ * Correspondence:Dalia-essa@hotmail.com (D.M.E.);
}

Scopus Author ID : 6506398816

Received: 16.08.2021; Revised: 16.10.2021; Accepted: 20.10.2021; Published: 19.12.2021

\begin{abstract}
In this search, the wool fabric was dyed with a natural dye Calligonum comosum (Callig. Co. dye); the dyeing process was applied under different conditions by changing dye bath temperature, time of dyeing, and $\mathrm{pH}$ of dye bath also using different mordants. Ultraviolet protection factor (UPF) was determined for each dyed wool sample. The role of these dying conditions on the via color strength analysis their effects on the reflectance spectra were investigated using the spectro-photometer tool, CIE tristimulus values, and the color parameters. The dye-ability strength and fastness to washing and perspiration properties of these wool samples dyed with (Callig. Co. dye) were carried out spectrophotometrically and evaluated the antimicrobial activity for blank and dyed wool fabrics via gram-positive and gram-negative was followed. The results showed that dyeing wool fabrics with (Callig. Co. dye) increased their protective abilities markedly, and they have effective protection against UV rays, also improving their antimicrobial activity. Moreover, Different conditions of the dye bath changed the optical properties noticeably. The present study will be useful for dermatologists advising patients regarding the UPF properties of clothes made from natural fabrics (wool) and dyed with natural colorants (Callig. Co. dye).
\end{abstract}

Keywords: Calligonum comosumdye; wool; UPF; optical properties; antibacterial properties; fastness properties.

(C) 2021 by the authors. This article is an open-access article distributed under the terms and conditions of the Creative Commons Attribution (CC BY) license (https://creativecommons.org/licenses/by/4.0/).

\section{Introduction}

Solar ultraviolet radiation (UVR) constitutes consists of three parts: UV-A (400-315 $\mathrm{nm})$, UV-B (315-290 nm), and UV-C (290-200nm). These radiations are transmitted in natural terrestrial sunlight in different percentages.UV-C and a large portion of UV-B do not reach the earth[1, 2]since it is filtrated by the upper atmosphere layer and the local conditions(attitude, clouds, latitude, etc.). UV-A decreases the immunological response of skin cells and causes a little visible reaction on the skin. The rest of UV-B was most responsible for developing skin cancer[3].

UV radiation can cause severe damage to human skin, plastics, timber, and other polymeric materials. This damage may be in the form of discoloration, chalking, and reduced mechanical properties. This situation has worsened due to the recent ozone depletion caused by the increased generation of manufactured free radicals species, such as nitric oxide, nitrous oxide, and oregano-halogen compounds [4]. 
Excessive exposure to sunlight increases the existence of skin cancer. Long time exposure to UV radiation results in sunburn, premature skin aging, allergies, skin cancer, Alzheimer's disease, and inflammatory disorders. Medical advisers suggest several means to protect human skin against UV radiation by avoiding exposure to the sun at its highest intensities, covering the skin surface by wearing clothes, and using sunscreens [3].

\subsection{Effect of $U V$ radiation on textile materials.}

Degradation occurs when textiles materials are exposed to UV radiation due to excitation in the polymer molecules and gradually loss of integrity which depends on the nature of the fabrics [5-8]. When UVR penetrates clothing materials, it causes photo-oxidation and some increase in the degree of crystallinity of clothing materials [7, 9]. Different types of interaction occur when the textile materials are hit by UV radiation, this interaction depends upon the substrate and its conditions[10-12]. The UV protection provided by apparel depends on the construction of the fabric, physical properties, i.e., thickness, porosity, the extension of the fabric, also chemical characteristics.,physicochemical nature of the fiber, dyeing and finishing treatment given to the fabric, moisture content, and presence of UV absorbers [13$18]$.

\subsubsection{Structure of fabric.}

As the fabric density and thickness for similar construction increase, the value of UPF increases and is dependent on fabric porosity [19] but also influenced by the nature of fibers [20]. UPF shows a better correlation with fabric weight and thickness than the porosity [21].

\subsubsection{Physicochemical nature of the fiber.}

The variation in ultraviolet transparency is due to the chemical nature of the fibers, which influences the UPF[22]. Synthetic fibers have a higher degree of absorption of ultraviolet radiation than natural fibers[23]. Protein fibers also have different effects on ultraviolet radiation penetration. Silk fabrics are usually finer and medium ultraviolet transmission [22].

Wool fabrics have lower transmission and higher absorption of UV radiation. Wool absorbs strongly in the region of $280 \mathrm{~nm}-400 \mathrm{~nm}$ and even beyond $400 \mathrm{~nm}$.

\subsubsection{Dyeing and finishing.}

The permeability to ultraviolet radiation of all textiles is affected by the dye used to color them. The absorption band of many dyes extends into the ultraviolet spectral region, depending on the dyes' chemical structure. Using the same fabric structure and dye, the darker the shade, the higher the UPF value[24]. To obtain high ultraviolet protection, a high concentration of premium dyes is used. These dyes contain conjugated molecules that disrupt UV radiation. Pigment dyed fabrics, including a resin, get high values for ultraviolet protection[25]. The type of dye or pigment, the absorptive groups present in the dyestuff, depth after dyeing, the uniformity, and additives influence the ultraviolet protection of the fabrics.

All dyes extracted from various natural sources have UPF within the range of 15-45 depending on the mordant used[26].

Personal apparel (including garments, shoes, hats, and fabric made for personal apparel) is sun-protective clothing, i.e., a claim of protective advantage against solar ultraviolet radiation is made[27]. 
The textile, which protects from sunlight, harmful UV light, is called a UV-protective textile by reducing the risk of skin injury associated with UV exposure or using a rating system that quantifies the amount of protection afforded[28].

By calculating the UPF value, we can know how much time can a person stay in the sun when fabric covers the skin compared with the length of time in the sun without fabric covering to obtain the same erythemal response. The endpoint is generally just perceptible skin Redding. The reverse of UPF, i.e., (1/UPF), is the penetration of erythema weighted transmission. No upper limit of the UPF value to indicate the protection provided.

\subsection{Type of protection.}

Many methods are used to quantify the protection of human skin from sunburn by covering it with fabrics.

\subsubsection{Precancerous skin lesion.}

Two dermatologists [29] have reported cases in which the appearance of or a number of skin tumors on the patient's body seemed directly related to the type of clothing worn [30].

\subsubsection{Photoaging protection.}

Biophysical parameters of skin color, skin moisture content, skin wrinkling, and skin elasticity were determined as a function of exposure to UV radiation [31].

\subsubsection{Skin-darkening protection.}

The darkness of skin was assessed using a chromo meter yielding the color L.a.b coordinates [31]. Fabrics can efficiently prevent tanning. Tanning can be seen as a surrogate for various other kinds of photodamage. To completely avoid any sign of tanning (skin pigmentation), UPF greater than 15 is required under the regime of irradiation used in this study.

\subsubsection{Skin moisture retention protection.}

Skin moisture content was determined before and after irradiation using a cornea meter skin conductivity/capacitance instrument. The results show that skin moisture content drops considerably with UV irradiation. However, they should use a protective cream.

\subsubsection{Wrinkle protection.}

The wrinkle is an important sign of photoaging. Wrinkle was measured by surface profile meter (i.e., analysis of shadow patterns). The formation of wrinkles was avoided when fabric covered the skin during UV exposure [32].

\subsubsection{Skin-elasticity protection.}

Skin elasticity was determined by a cutometer. A tube with integrated light barrier measures by means of repetitive suction skin extension and rebound time of the skin. When fabric covered the skin that was reduced the effect of elasticity drop.

There are other useful factors that are visually obvious. 


\subsubsection{Optical whitening agents (OWAs).}

The optical whitening agent (OWAS) is included because they whiten (white fabrics) and brighten(colored fabric).OWAS convert apportion of incident UV radiation (near 360nm) to the visible blue wavelength and reflect the visible blue wavelength (at about $430 \mathrm{~nm}$ ); secondarily, the presence of OWAS on fabric enhances UPF value because they absorb better in UVA region than in the UVB region. They have an absorption weakness at about $308 \mathrm{~nm}$, a wavelength that is a powerful producer of erythema.

\subsubsection{Fabric shrinkage.}

After laundering, a small shrinkage of fabrics can lead to improving the UPF value of the fabric significantly. The fabric cover factor has a tremendous influence on UV Transmission that goes directly through the fabric. They are not scattered because they never interact with the fibers[33, 34].

The proportion of fabric surface area filled with fiber to the total fabric surface area is known as the cover factor. As the percent cover factor increases in small increments, the UPF increases rapidly. The importance of the cover factor is a high fabric parameter because it determines the probability of a UV ray striking a fiber. Conversely, as the porosity percent of the fabric is high, the probability that rays are directed perpendicular to the fabric surface is great[33].

\subsubsection{Fabric depth of shade.}

The description of a fabric color may be specified by its hue (e.g., red, orange, yellow, blue, or green) and its depth of shade. The fabric depth of the shade is related to the lightness or darkness of the color (hue) of the fabric. The fabric of dark shades, i.e., containing more dye, had higher UPF values than less of the same dye (light shades) [35].

\subsubsection{Moisture and swelling.}

Wet garments have a lower ultraviolet protection factor than the same dry garment. This is due to the presence of water in interstices reducing UV radiation scattering, which increases the UV radiation permeability [33.36]. The phenomenon is caused by moisture absorption, which reduces UV transmittance.

\subsubsection{Ultra-violet absorbers.}

Ultra-violet absorbers are organic/inorganic colorless compounds with strong absorption in the UV wavelength range of $290-360 \mathrm{~nm}$. [37]. They convert electronic excitation energy into thermal energy. They function as radical scavengers and singlet oxygen quenchers.

Optical brightening is often applied to enhance the whiteness of texts, by ultraviolet excitation and visible blue emission. This is caused by the transition of electrons from conjugated or aromatic compounds[38]. Many optical brightening agents absorb in the UV-A part of the day or night spectrum but have a weak absorption in UV absorption around $308 \mathrm{~nm}$, which causes skin diseases [39]. 


\section{Materials and Methods}

\subsection{Materials and chemicals.}

Pure wool fabrics $100 \%$ (weight $176.71 \mathrm{~g} / \mathrm{m}^{2}$ ) were supplied by Golden-Tex Co., Egypt. Wool fabric was scoured in a bath containing $2 \mathrm{~g} / \mathrm{l}$ nonionic detergent and $5 \mathrm{~g} / \mathrm{l}$ sodium sulfate at liquor ratio $1: 50$ at $45^{\circ} \mathrm{C}$, and the temperature remained constant for $30 \mathrm{~min}$. Finally, wool was rinsed with warm water and air-dried[40].

\subsection{Extraction of dye.}

The dye used was extracted from the barks of a plant named Calligonum comosum. Calligonum comosum plant barks were crushing, and $20 \mathrm{~g}$ of it was weighed and dissolved in $100 \mathrm{~mL}$ distilled water to obtain a concentrated dye solution. The solution was left for 24 hours for complete extraction. The dye liquor was heated slowly until $100^{\circ} \mathrm{C}$, then stilled at this temperature for one hour to get the required quantity of the extracted dye. The extraction is cooled, then filtrated to get rid of unwanted portions. Finally, the dye liquor was measured to the original level by adding distilled water[41].

\subsection{Characteristics of the Extracted Dye.}

The extracted dye was characterized by Ultraviolet-visible spectroscopy. Figure 1 shows the absorbance spectrum of the extracted dye "Calligonum comosum plant barks" all over the UV-VIS range using LAMBADA 35 Spectrophotometer, Perkin-Elmer, USA, making clear that the maximum absorbance for the dye is at a wavelength $(\lambda \max ) 460 \mathrm{~nm}$ in the visible range.

Table 1 presents the characteristic functional group using Nicolet 380 FTIR Spectrophotometer, USA, of $4 \mathrm{~cm}-1$ resolution and 32scans, with Attenuation Total Reflection (ATR) and Zinc selenide crystal.

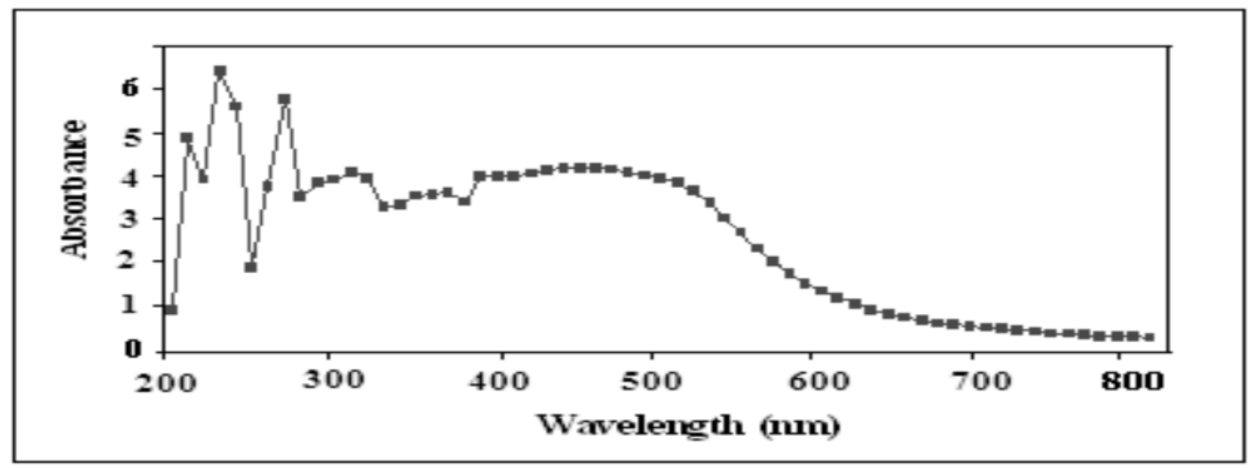

Figure 1. The absorbance spectra of the extracted dye.

Table 1. FTIR analysis of Calligonum comosum dye showing its peak intensity values of its characteristics functional bands.

\begin{tabular}{c|c|c} 
Wavelength $\left(\mathbf{c m}^{-\mathbf{1}}\right)$ & Characteristic functional bands & Peak intensity value $(\%)$ \\
\hline 522.44 & O-H twisting & 70.2 \\
1075.65 & Sulpher cystine monoxide & 71.3 \\
1240.53 & C-O stretching vibration & 62.8 \\
1402.15 & C-C benzene ring vibration & 74.0 \\
1650.97 & C=O antisymmetric stretching & 100.2 \\
2924.50 & C-H Vibration & 62.8 \\
3411.91 & O-H Stretching band & 99.2
\end{tabular}




\subsection{Dyeing samples.}

The wool fabrics were dyedwith Calligonum comosum dye at different conditions, and dyed samples were divided into four groups: group (1) the wool samples dyed at different temperatures $\left(20,40,60,80^{\circ} \mathrm{C}\right)$ at $\mathrm{pH} 6$ and dyeing time $45 \mathrm{~min}$., group (2) the wool samples dyed at different $\mathrm{pH}(2.3 .4 .5 .6)$ at $80^{\circ} \mathrm{C}$ and dyeing time $45 \mathrm{~min}$., group (3) the samples dyed at different dyeing time (15,30,45,60 min.) at $80^{\circ} \mathrm{C}$ and $\mathrm{pH} 6$ finally, group (4) the wool samples dyed and treated with different mordents Potassium aluminum sulfate (alum) (KAl $\left.\left(\mathrm{SO}_{4}\right)_{2 .} 12 \mathrm{H}_{2} \mathrm{O}\right]$, ferrous chloride $\left(\mathrm{FeCl}_{2}\right)$ and ferrous sulfate $\left(\mathrm{FeSO}_{4} .7 \mathrm{H}_{2} \mathrm{O}\right)$ were used at $\mathrm{pH} 6$, $80^{\circ} \mathrm{C}$ and dyeing time $45 \mathrm{~min}$.

\subsection{Evaluation of dyed samples.}

\subsubsection{Ultra-violet protective factor (UPF).}

UPF was measured using UV-VIS double beam spectrophotometer (Perkin-Elmer, Lambda 35, Diffuse transmission technique) according to the American standard (ASTM D6603-2000) and AATCC test method [AATCC 183- 2000]. The following equation was used to calculate UPF:

$$
\mathrm{UPF}=\frac{\sum_{280 \mathrm{~nm}}^{400 \mathrm{~nm}} \mathrm{E}, S, \Delta}{\sum_{280 \mathrm{~nm}}^{400 \mathrm{~mm}} \mathrm{E}, \mathrm{S}, \Delta}
$$

Where: $\mathrm{E} \lambda=$ Relative Erythermal effectivness function, $\mathrm{S} \lambda=$ solar spectral irradiance in Wm$2 \mathrm{~nm}^{-1}, \mathrm{~T} \lambda=$ spectral transmittance of fabric, $\Delta \lambda=$ measured wavelength interval $(\mathrm{nm})$;

The tested samples were classified according to their UPF values: <15 Poor, 15 to 24 Good, 25-39 Very Good, > 39 Excellent [42].

\subsubsection{Opticalmeasurements of the dyed samples.}

The color coordinates $\left(\mathrm{L}^{*} \mathrm{~b}^{*} \mathrm{a} *\right)$ and color strength $(\mathrm{K} / \mathrm{S})$ values of all examined dyed samples were determined using an SDL Optimatch Color Matching System, England.

The positive values of $a$ and $b$ indicate redness and yellowness, respectively, while negative values indicate greenness and blueness. L parameter measures the brightness of the samples and varies from 100 for perfect white to zero for black. The lower the value of L, the greater the depth of the color.

\subsubsection{Colorfastness properties of al dyed samples.}

The fastness properties of washing were determined according to ISO 105-C06 (2010), while fastness to perspiration was performed according to ISO 105-E04-(2019).

\subsubsection{Antibacterial evaluation.}

We used the standard method (AATCC Test Method 147-2004 Antibacterial Activity Assessment of Textile Materials: Parallel Streak Method) to evaluate the antibacterial activity of all samples under test. Two types of bacteria were used, Staphylococcus aureus (Staph. aureus) as Gram-positive(g+ve) bacteria; and Escherichia coli (E. coli) as Gram-negative (gve) bacteria. The antibacterial assessment was prepared on nutrient agar and incubated at $37^{\circ} \mathrm{C}[43]$. The antibacterial activity of all examined wool fabrics was evaluated after the 
specified contact time $(24 \mathrm{~h})$. It is calculated by measuring the inhibition zone against the growth of Staphylococcus aureus and Escherichia coli.

\section{Results and discussion}

\subsection{Group 1: changing temperature.}

\subsubsection{Ultraviolet protective factor UPF determination.}

Basant et al. found that each dye has an optimum dyeing temperature and that dye uptake will continue to increase with increased temperature. This is due to the reduction of aggregation in the dye bath, and hence, the quantity of dye available to the fiber in the dye is increased [44].

It is clear from table 2that the increase in dye bath temperatures from $20^{\circ} \mathrm{C}$ to $80^{\circ} \mathrm{C}$ causes an increase in the UPF value of the dyed wool fabrics above that of the blank one. The higher dye attraction into the dyed fabrics and enhancing the reaction efficiency between the dye and the fabric due to increasing temperature causes this increase in UPF values. Enhancing the reaction efficiency between the dye and the fabric was accompanied by increasing the dyed fabric's carboxyl content.

All dyed wool samples could be classified as having excellent protection factors (above 39). Also, the dark-colored fabrics gave more protection against intense UV radiation when using synthetic dyes[45]. It shows that dyeing fabrics in deeper shads and darker colors improves sun protection properties. The high bulk structure effect of the natural dyes causes blocking of the holes in the fabric to prevent holes effect; this causes improvement of UVprotection property of the dyed fabrics, so the transmission of UV-radiation through the fabric structure will be minimized, i.e., better UPF rating [35].

Figure 2 shows the relation between absorbance and wavelength range from 290nm to $400 \mathrm{~nm}$ for the dyed wool fabrics with Calligonum comosum dye at different temperatures.

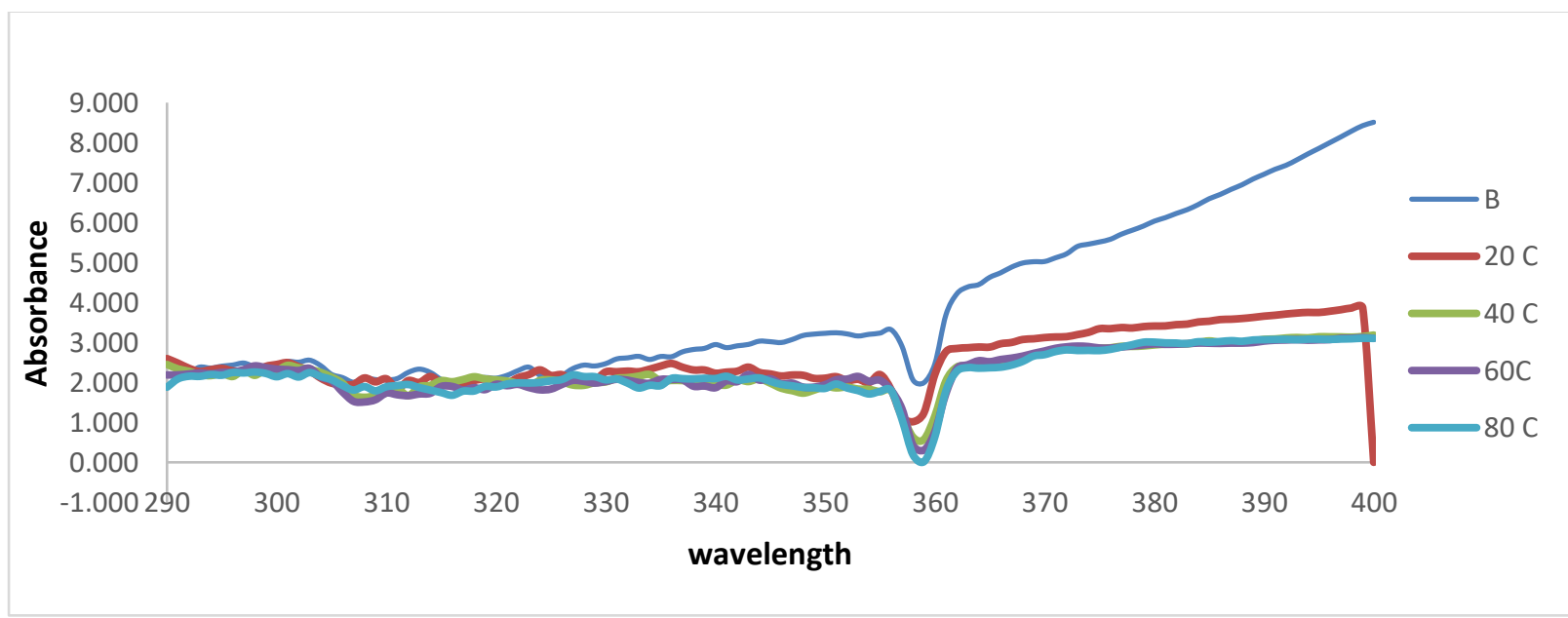

Figure 2. Relation between absorbance and wavelength at different temperatures.

\subsubsection{Color strength (K/S) determination.}

Table 2 represents the results of the calculated relative color strength (using Kubelka Munk equation), determined from diffuse reflectance of the wool fabrics measured at wavelength $460 \mathrm{~nm}$. It is clear that at all dye bath temperatures of wool that $\mathrm{K} / \mathrm{S}$ values increase by increasing temperature. It is well known that affinity, the heat of sorption, and accessibility 
are the most important parameters which affect the exhaustion of natural dyes onto substrates at high temperatures[44]. This dye gives bright color at higher temperatures due to its easy absorption on wool.

Table 2. Variation between K/S and UPF values for the four investigated groups.

\begin{tabular}{c|c|c} 
Sample conditions & UPF & $\begin{array}{c}\text { K/S at } \\
\boldsymbol{\lambda} \mathbf{4 6 0} \mathbf{~ n m}\end{array}$ \\
\hline Blank & & -- \\
\hline Group (1): Dyeing Temperature ${ }^{\mathbf{0}} \mathbf{C}$ & 41.84 & \\
\hline 20 & & 1.7990 \\
60 & 46.09 & 2.3135 \\
80 & 49.25 & 2.655 \\
\hline Group (2): $\mathbf{p H}$ values & 51.36 & 3.125 \\
\hline 2 & 53.04 & 2.7956 \\
3 & & 2.7047 \\
4 & 50.32 & 2.9583 \\
5 & 48.16 & 2.7635 \\
6 & 48.90 & 2.9287 \\
\hline Group (3): Dyeing time (min.) & 49.59 & \\
\hline 15 & 47.42 & 2.4083 \\
30 & & 3.8624 \\
45 & 50.70 & 3.0554 \\
\hline 60 & 49.81 & \\
\hline Group (4): Different mordents & 46.35 & 2.3289 \\
Fotassium aluminum sulfate (alum) & 49.69 & 3.2612 \\
Ferrous sulfate & & 2.8794
\end{tabular}

3.2. Group 2: changing $p H$.

3.2.1. Ultraviolet protective factor UPF determination.

Etters $\mathrm{JN}$ determined that the $\mathrm{pH}$ of the dye bath must be controlled to obtain good shade and wash fast characteristics. The $\mathrm{pH}$ of the dye bath is one of the most important parameters. The liquor used for dyeing must be buffered for some dyes which are sensitive to $\mathrm{pH}[46]$.

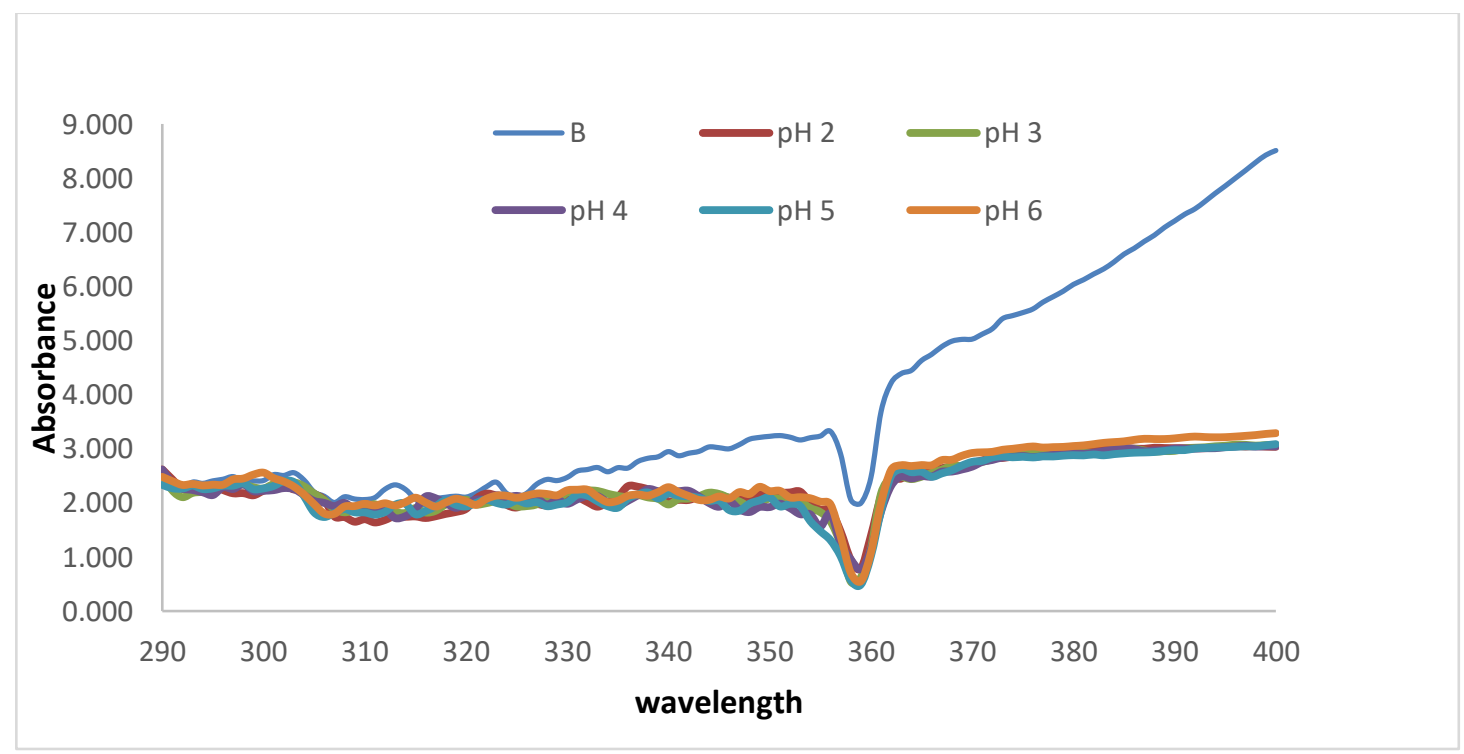

Figure 3. Relation between absorbance and wavelength at different $\mathrm{pH}$.

Table 2 represents the effect of the $\mathrm{pH}$ value of the dye bath on the UV protection factor (UPF) of the blank and dyed fabrics by Calligonum comosum dye. Increasing $\mathrm{pH}$ dye bath 
values leads to a decrease in the UPF values at $\mathrm{pH}=2,3$, and 4; then, an increase occurs at $\mathrm{pH}=5$ followed by more decrease at $\mathrm{pH}=6$. It is noticed that all samples have excellent $\mathrm{UV}$ protection classification. The increase in UPF values may be due to the increase in the number of $-\mathrm{CH}$ molecules in the dyed fabrics.

The relation between absorbance and wavelength in the range from $290 \mathrm{~nm}$ to $400 \mathrm{~nm}$ for the dyed wool fabrics with Calligonum comosum dye at different $\mathrm{pH}$ is shown in Figure 3.

\subsubsection{Color strength $(\mathrm{K} / \mathrm{S})$ determination.}

The values of the color strength of these examined substrates are tabulated in Table 2 and taken to measure the dyeability of the examined samples dyed at different $\mathrm{pH}$ values of the dye bath. The color strength decrease from $\mathrm{pH}=2$ to $\mathrm{pH}=3$, then increases markedly at $\mathrm{pH}=4$, another decrease at $\mathrm{pH}=5$, then an increase at $\mathrm{pH}=6$; i.e., wavy trend.

\subsection{Group 3: changing time.}

\subsubsection{Ultraviolet protective factor UPF determination.}

Table 2 shows that the UPF values of the dyed wool fabrics decreased by increasing the dyeing time 15, 30, and 45min. But after $60 \mathrm{~min}$ of dyeing time, the UPF increased again. All the samples still have excellent UPF classification.

The relation between absorbance and wavelength in the range from $290 \mathrm{~nm}$ to $400 \mathrm{~nm}$ is shown in figure 4 for the dyed wool fabrics with Calligonum comosum dye at different times.

\subsubsection{Color strength $(\mathrm{K} / \mathrm{S})$ determination.}

The color strength K/S of dyed wool fabrics increased by increasing dyeing time, resulting in deeper colors on the fabrics.

However, the relationship of K/S with UPF is limited to the same fabric type, and the results cannot generalize across different weave structures[47].

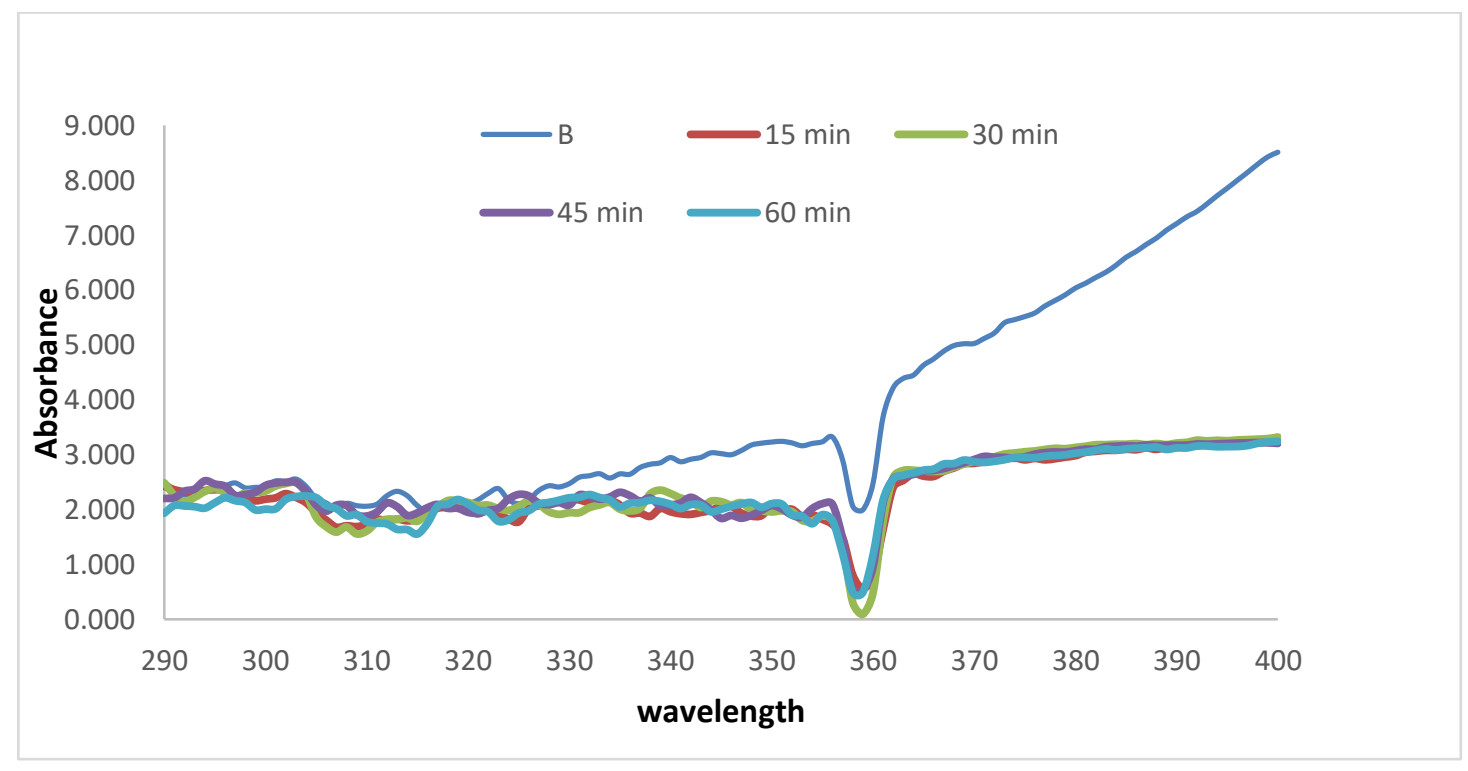

Figure 4. Relation between absorbance and wavelength at different dyeing time.

The UPF values depend on many factors of fabrics construction, such as pores, thickness, weight, and processing parameters such as dyeing and finishing. 
Also, the dependence of K/S on the absorbing properties of colorants in the visible region of the spectrum does not influence the absorption characteristics of colorants in the UPF region. Besides, hydrogen bonds are formed between the hydroxyl group of the dye used and the chemical groups in the fabrics [48]. Thus the numbers of these polar groups in the dye and the substrate increase, i.e., dye uptake increases, which improves the lightfastness.

\subsection{Group 4: Changing mordents.}

\subsubsection{Ultraviolet protective factor UPF determination.}

The three dyed mordanted wool samples have excellent UPF and are nearly in the same range (52.66- 52.93 and 52.16), as shown in Table2.

The function of the metallic salt mordant is the formation of coordinate bonds with the functional group of the dye molecules and the textile substrate. In addition, it is observed that mordant may increase fastness, shade variation, dye exhaustion, and other fabric properties[49].

The different mordants give different colors and shades, encouraging natural dyes instead of synthetic ones. This may be due to the change in the chemical bonds in the fabric, dye, and the mordant, i.e., preferential light absorption at a particular wavelength[50].

By following the values of UPF of the three dyed wool fabrics and then mordanted by Potassium aluminum sulfate (alum) $\left(\mathrm{K} \mathrm{Al}\left(\mathrm{SO}_{4}\right)_{2} .12 \mathrm{H}_{2} \mathrm{O}\right.$ ], ferrous chloride $\left(\mathrm{FeCl}_{2}\right)$, and ferrous sulfate $\left(\mathrm{FeSO}_{4} .7 \mathrm{H}_{2} \mathrm{O}\right)$ in Table 2 , noticed that the three samples have nearly UPF value (excellent). No relation is observed between these UPF values and K/S values.

Figure 5 represents the relation between absorbance and wavelength range from 290 $\mathrm{nm}$ to $400 \mathrm{~nm}$ for the dyed wool fabrics with Calligonum comosum dye using different mordents.

\subsubsection{Color strength (K/S) determination.}

The variation in the optical parameter K/S may be taken to present the variation in the chemical groups of different mordants.

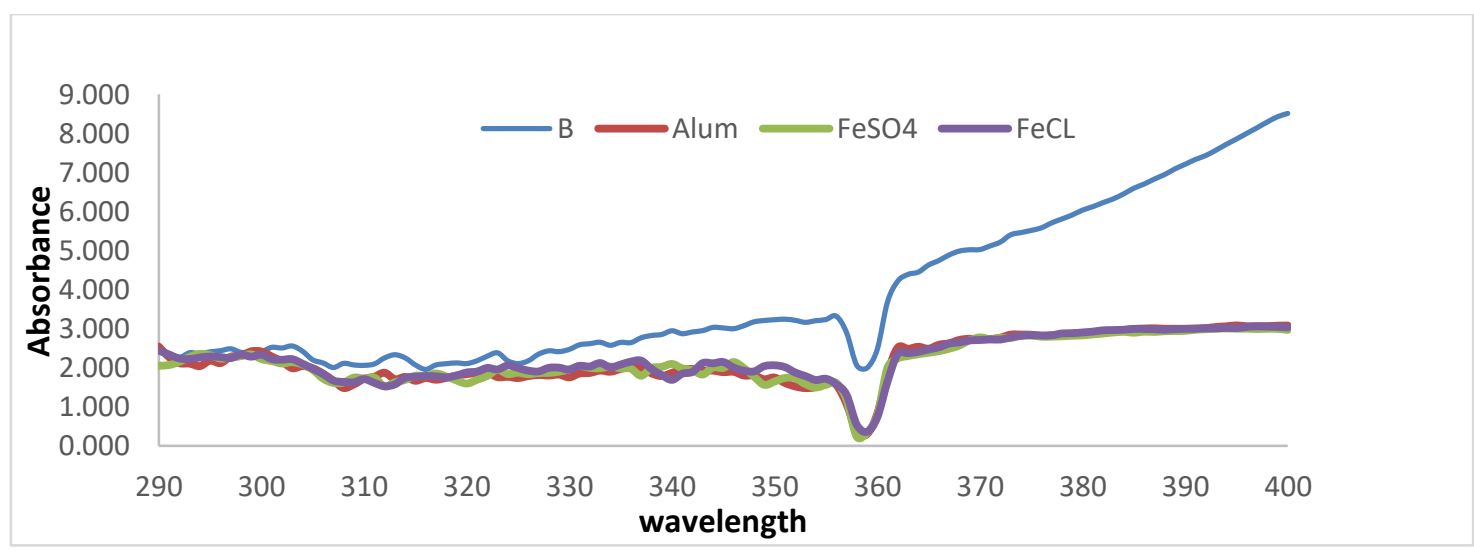

Figure 5. Relation between absorbance and wavelength using different mordents.

This led to new color centers in the dyed wool fabric. These color centers are formed due to the change in the molecular configuration as a result of the change in the chemical bonds between the dye, the mordant, and the wool fabrics samples. Other molecular species formed due to bonds occur when the formation of active free radicals, which may combine [50]. 
In general, the content of functional polar groups in fabrics was affected the dyeing affinity of fabrics. It is well known that wool has many functional groups, so the polarity of protein fibers is higher than that of cellulose fiber. The K/S value was in the order of wool>nylon>silk>cotton fabric for all-natural colorants.It was found that this order of dyeing affinity matched the order of polarity/functional group content of fabrics very well [40].

The optical studies can differentiate between different kinds of fabrics with different types of mordents present in small quantities.

The value of (K/S) of this group which contains wool fabrics dyed with Calligonum comosum dyes, then mordanted with different mordants are calculated and represented in Table 2. The values are less than those of the above three groups. The highest K/S value was related to $\mathrm{FeSO}_{4}$ mordant. This can be seen easily in its fabric color. Wool fabrics mordanted by alum have the lowest one. The dyed wool fabrics mordanted with $\mathrm{Fe} \mathrm{Cl}$ have $\mathrm{K} / \mathrm{S}$ value lay between these two mordants.

\subsection{Determination $L, a \& b$ parameters.}

Table 3 represents the color parameters L (brightness), a, and b (color components) of all the wool fabrics samples. L for group 1 (changing in temperature) decreases by increasing temperature, i.e., wool fabric samples become brighter. While group 2 (changing $\mathrm{pH}$ ), little increase at $\mathrm{pH}=3$ then nearly constant at $\mathrm{pH}=4.5$ and 6 . Group 3 (changing time bath time), $\mathrm{L}$ drops after 30 and 45 minutes, then markedly increases after 60 minutes of immersing, i.e., darker color. Wool samples mordanted by different mordants show different L values, and the lowest one occurs by using $\mathrm{FeSO}_{4}$ mordants.

Following the color component (a) for group 1 increases continuously by increasing temperature from $20^{\circ} \mathrm{C}$ to $80^{\circ} \mathrm{C}$, i.e., wool samples got redness in color on account of green color. Also, for group 2, the color parameter (b) decreases steeply, reaching $\mathrm{pH}=5$, then increases at $\mathrm{pH}=6$, so the wool sample goes to the blue side and at $\mathrm{pH}=6$ returns to the yellow one. Finally, with respect to group 3 (a), component decreases noticeably, i.e., acquire blueness in color.

The (b) color parameter for group 1 drops by increasing temperature, so the color of wool fabrics becomes blueness. Group 2 acquires blueness color, which becomes nearly constant at $\mathrm{pH}=5$ and 6 . Group 3 decreases markedly for all dye bath time, but at 60 minutes, the wool fabrics return to yellowness since a high increase in the $b$ component occurs. The wool-mordanted dyed fabrics have different (b) color parameters, but the lowest one (bluer) is that for $\mathrm{FeSO}_{4}$, but alum and $\mathrm{FeCL}$ have the same (b) values.

\subsection{Percentage $U V-A / U V-B$ ratio (UVR).}

The Percentage UV-A and UV-B transmission values are useful in better understanding the sun-protective properties of fabrics.

The values of the ultraviolet protection factor (UPF) and the percent of UV transmission for UV-A and UV-B ranges were calculated and shown in table 4. The values reflect the higher protection against UV radiation when dyeing wool fabrics with Calligonum comosum dyes.

It is clear that from table 4, the relative erythemal spectral effectiveness for all the wool fabrics dyed is higher in the UV-B region compared to the UV-A region, i.e., the UPF values depend primarily on the transmission in the UV-B region. Group 2 has significant transmittance and hence a low UPF. 
Table 3. Results of color parameters L, a, b, for all groups of dyed wool fabrics.

\begin{tabular}{|c|c|c|c|}
\hline Sample conditions & $\mathbf{L}$ & $\mathbf{A}$ & b \\
\hline \multicolumn{4}{|l|}{ Group (1): Dyeing Temperature ${ }^{0} \mathrm{C}$} \\
\hline 20 & 54.21 & 10.10 & 13.19 \\
\hline 40 & 55.03 & 10.45 & 14.51 \\
\hline 60 & 53.47 & 9.83 & 13.57 \\
\hline 80 & 53.88 & 8.21 & 12.52 \\
\hline \multicolumn{4}{|l|}{ Group (2): pH values } \\
\hline 2 & 53.04 & 9.53 & 12.27 \\
\hline 3 & 68.93 & 6.10 & 18.18 \\
\hline 4 & 61.12 & 8.48 & 15.81 \\
\hline 5 & 56.65 & 9.17 & 14.47 \\
\hline 6 & 58.97 & 10.07 & 15.25 \\
\hline \multicolumn{4}{|l|}{ Group (3): Dyeing time (min.) } \\
\hline 15 & 52.73 & 10.25 & 11.72 \\
\hline 30 & 49.4 & 9.02 & 9.09 \\
\hline 45 & 49.45 & 8.50 & 8.76 \\
\hline 60 & 57.88 & 7.78 & 15.17 \\
\hline \multicolumn{4}{|l|}{ Group (4): Different mordents } \\
\hline Potassium aluminum sulfate (alum) & 53.52 & 8.72 & 11.82 \\
\hline Ferrous sulfate & 46.87 & 4.51 & 6.27 \\
\hline Ferrous chloride & 52.47 & 7.23 & 11.81 \\
\hline
\end{tabular}

Table 4. The percent UV transmittance for the four groups of dyed wool fabrics.

\begin{tabular}{|c|c|c|c|}
\hline \multirow[t]{2}{*}{ Sample conditions } & \multicolumn{2}{|c|}{ UV transmission \% } & \multirow{2}{*}{ UV-A/ UV-B } \\
\hline & UV-A & UV-B & \\
\hline Blank & 4.29 & 2.31 & 1.857 \\
\hline $\begin{array}{c}\text { Group (1): Dyeing Temperature }{ }^{\mathbf{0}} \mathbf{C} \\
20 \\
40 \\
60 \\
80\end{array}$ & $\begin{array}{l}2.68 \\
2.34 \\
2.33 \\
2.30\end{array}$ & $\begin{array}{l}2.24 \\
2.10 \\
2.04 \\
1.98\end{array}$ & $\begin{array}{l}1.196 \\
1.114 \\
1.142 \\
1.162\end{array}$ \\
\hline \multicolumn{4}{|l|}{ Group (2): pH values } \\
\hline $\begin{array}{l}2 \\
3 \\
4 \\
5 \\
6\end{array}$ & $\begin{array}{l}2.38 \\
2.36 \\
2.35 \\
2.32 \\
2.48\end{array}$ & $\begin{array}{l}2.07 \\
2.13 \\
2.11 \\
2.10 \\
2.20\end{array}$ & $\begin{array}{l}1.150 \\
1.103 \\
1.115 \\
1.105 \\
1.127\end{array}$ \\
\hline \multicolumn{4}{|l|}{ Group (3): Dyeing time (min.) } \\
\hline $\begin{array}{l}15 \\
30 \\
45 \\
60\end{array}$ & $\begin{array}{l}2.38 \\
2.43 \\
2.45 \\
2.42\end{array}$ & $\begin{array}{l}2.06 \\
2.08 \\
2.21 \\
1.99\end{array}$ & $\begin{array}{l}1.155 \\
1.168 \\
1.109 \\
1.216\end{array}$ \\
\hline \multicolumn{4}{|l|}{ Group (4): Different mordents } \\
\hline $\begin{array}{c}\text { Potassium aluminum sulfate (alum) } \\
\text { Ferrous sulfate } \\
\text { Ferrous chloride }\end{array}$ & $\begin{array}{l}2.23 \\
2.22 \\
2.29\end{array}$ & $\begin{array}{c}2.01 \\
1.9 \\
2.03\end{array}$ & $\begin{array}{l}1.109 \\
1.116 \\
1.128\end{array}$ \\
\hline
\end{tabular}

The transmission data and its corresponding UPF tabulated in Table 4 noticed that all the wool fabrics dyed with (Calligonum conrosum) natural dye under different conditions caused a marked reduction in UVR transmission through it. This is so clear for dyed samples at different temperatures (group 1), which have excellent UV protection against UVR when 
compared with other dyed factors. Dyes react like additives and improve UV protection abilities because they absorb UV radiation in the visible and UV radiation band.

\subsection{Result of color fastness for perspiration and washing.}

Tables (5-8) show the data for colorfastness for perspiration and washing, which indicates that the four groups of the wool fabrics dyed with Calligonum comosum have colorfastness ranges between $4 / 5$ and 4 .

Table 5. Effect of different $\mathrm{pH}$ on colorfastness for perspiration and washing.

\begin{tabular}{|c|c|c|c|c|c|c|c|c|c|}
\hline \multirow[t]{3}{*}{ pH } & \multicolumn{3}{|c|}{ Washing } & \multicolumn{3}{|c|}{$\begin{array}{c}\text { Acidic } \\
\text { perspiration }\end{array}$} & \multicolumn{3}{|c|}{ Alkali perspiration } \\
\hline & \multirow{2}{*}{ Alt. } & \multicolumn{2}{|c|}{ Stain. } & \multirow{2}{*}{ Alt. } & \multicolumn{2}{|c|}{ Stain. } & \multirow{2}{*}{ Alt. } & \multicolumn{2}{|c|}{ Stain. } \\
\hline & & & $\mathrm{C}$ & & & C & & & $\mathrm{C}$ \\
\hline 2 & 4 & $4 / 5$ & $4 / 5$ & 4 & & $4 / 5$ & 4 & $4 / 5$ & 4 \\
\hline 3 & $4 / 5$ & $4 / 5$ & $4 / 5$ & $4 / 5$ & $4 / 5$ & $4 / 5$ & $4 / 5$ & 4 & 4 \\
\hline 4 & $4 / 5$ & $4 / 5$ & $4 / 5$ & $4 / 5$ & $4 / 5$ & $4 / 5$ & 4 & 4 & 4 \\
\hline 5 & $4 / 5$ & $4 / 5$ & $4 / 5$ & $4 / 5$ & $4 / 5$ & $4 / 5$ & 4 & 4 & 4 \\
\hline 6 & $4 / 5$ & $4 / 5$ & $4 / 5$ & 4 & & 4 & 4 & 4 & 4 \\
\hline
\end{tabular}

Table 6.Effect of different temperatures on colorfastness for perspiration and washing.

\begin{tabular}{|c|c|c|c|c|c|c|c|}
\hline \multirow[t]{3}{*}{ Temp. ${ }^{\circ} \mathrm{C}$} & \multicolumn{3}{|c|}{ Washing } & \multicolumn{2}{|c|}{$\begin{array}{c}\text { Acidic } \\
\text { perspiration }\end{array}$} & \multicolumn{2}{|c|}{ Alkali perspiration } \\
\hline & \multirow{3}{*}{$\begin{array}{l}\text { Alt. } \\
4 / 5 \\
\end{array}$} & \multirow{2}{*}{\multicolumn{2}{|c|}{\begin{tabular}{ll}
\multicolumn{2}{c}{ Stain. } \\
$\mathrm{W} \quad \mathrm{C}$
\end{tabular}}} & \multirow[t]{2}{*}{ Alt. } & \multirow{2}{*}{$\begin{array}{l}\text { Stain. } \\
\text { W } \quad \text { C }\end{array}$} & \multirow[t]{2}{*}{ Alt. } & Stain. \\
\hline & & & & & & & W \\
\hline $\begin{array}{l}\text { Room } \\
\text { Temp. }\end{array}$ & & $4 / 5$ & $4 / 5$ & $4 / 5$ & $4 / 5$ & $4 / 5$ & $4 / 5 \quad 4 / 5$ \\
\hline 40 & $4 / 5$ & $4 / 5$ & $4 / 5$ & $4 / 5$ & $4 / 5$ & 4 & 4 \\
\hline 60 & $4 / 5$ & $4 / 5$ & $4 / 5$ & $4 / 5$ & $4 / 5$ & 4 & $4 / 5$ \\
\hline 80 & $4 / 5$ & $4 / 5$ & $4 / 5$ & $4 / 5$ & $4 / 5$ & $4 / 5$ & $4 / 5$ \\
\hline
\end{tabular}

Table 7. Effect of different times on colorfastness for perspiration and washing.

\begin{tabular}{|c|c|c|c|c|c|c|c|c|c|}
\hline \multirow[t]{2}{*}{ Time mln. } & \multicolumn{3}{|c|}{ Washing } & \multicolumn{3}{|c|}{$\begin{array}{c}\text { Acidic } \\
\text { perspiration }\end{array}$} & \multicolumn{3}{|c|}{ Alkali perspiration } \\
\hline & \multirow{2}{*}{$\begin{array}{l}\text { Alt. } \\
4 / 5\end{array}$} & \multicolumn{2}{|c|}{$\underset{\text { W }}{\text { Stain. }}$ C } & \multirow{2}{*}{\begin{tabular}{|l|} 
Alt. \\
$4 / 5$
\end{tabular}} & \multicolumn{2}{|c|}{$\underset{\mathrm{W}}{\text { Stain. }} \mathrm{C}$} & \multirow{2}{*}{$\begin{array}{l}\text { Alt. } \\
4 / 5\end{array}$} & \multicolumn{2}{|c|}{ W ${ }^{2}$ Stain. } \\
\hline 15 & & $4 / 5$ & $4 / 5$ & & $4 / 5$ & & & $4 / 5$ & 4 \\
\hline 30 & 4 & $4 / 5$ & $4 / 5$ & 4 & & & 4 & 4 & 4 \\
\hline 45 & $4 / 5$ & $4 / 5$ & $4 / 5$ & $4 / 5$ & $4 / 5$ & $4 / 5$ & 4 & $4 / 5$ & 4 \\
\hline 60 & 4 & 4 & $4 / 5$ & 4 & 4 & 4 & 4 & 4 & $3 / 4$ \\
\hline
\end{tabular}

Table 8. Effect of different mordents on colorfastness for perspiration and washing.

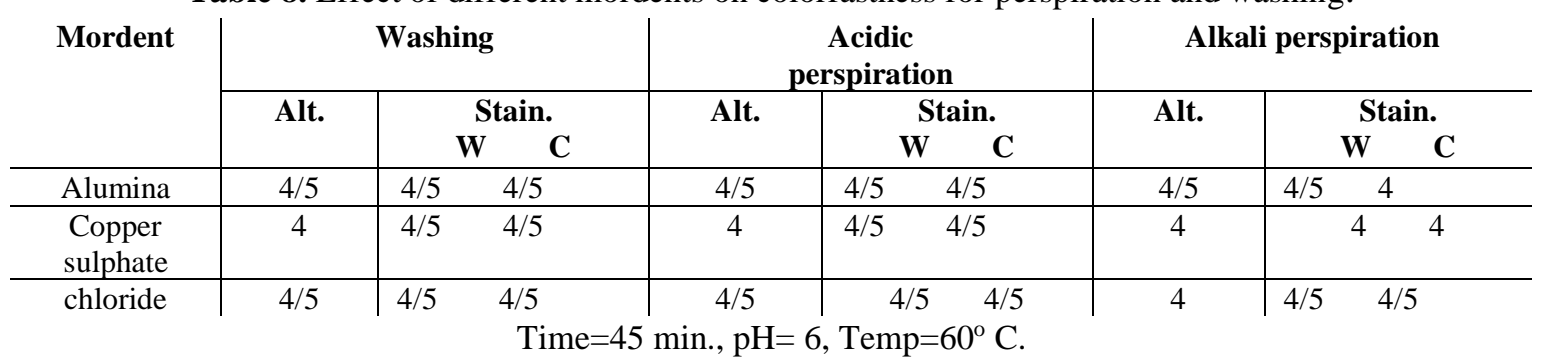

\subsection{Antibacterial properties.}

The antibacterial properties for all the four groups of the wool fabrics dyed was evaluated towards gram-negative bacteria (Escherichia coli) and gram-positive bacteria (Staphylococcus aureus) after the specified contact time (24h), where their activity was 
calculated by measuring the inhibition zone against the growth of each bacteria type. The results indicated that the highest dye bath temperature, long time immersing or bath of $\mathrm{pH}=6$ displays good inhibitory effect against the Gram-positive and noticeable activity against the negative bacteria.

\section{Conclusions}

In this research, it can be concluded that a new eco-friendly natural dye (calligonum conrosum) in the form of crashed barks was used to dye wool fabrics. The steps of dyeing were applied easily with low costs taking into account the following legal environment conditions. Therefore, the disadvantage of synthetic dyes was avoided. The accurate measurements of UPF and K/S using the spectrophotometric tool can be used to improve protein fabrics characteristics. The UPF values were calculated using UV diffuse transmission. The intensity and percent transmission of UV-A through wool fabrics are higher than that of UV-B. An increase of the UV absorbing activity in the dyed wool fabricsmeans protecting the body against radiation. The UPF values for all dyed samples under different dyeing conditions are not affected by laundering up to 30 wash cycles. The UV protective properties of clothes made from natural fibers and dyed with natural dyes will be useful for dermatologists advising patients. All the wool fabrics dyed with Calligonum comosum show very good fastness properties for washing and perspiration. Dyeing wool fabrics with the natural dye Calligonum comosum improves its antimicrobial activity and has a beneficial effect in controlling the pathogenic microbial organisms.

\section{Funding}

This research received no external funding.

\section{Acknowledgment}

The authors gave great thanks to prof. Nabawia Abd El-Zaherfor providing with Calligonum comosum natural dye.

\section{Conflicts of Interest}

The authors declare no conflict of interest.

\section{References}

1. D'Orazio, J.; Jarrett, S.; Amaro-Ortiz, A.; Scott, T.UV Radiation and the Skin.International Journal of Molecular Sciences2013, 14, 12222-12248, https://doi.org/10.3390/ijms140612222.

2. Chakraborty, N.; Sharma, V.; Gautam, P.Enhancing UV Protection of Cotton through Application of Novel UV Absorbers. JTATM 2014, 9.

3. Biological effects of ultraviolet radiation relevant to health with 12 particular references to sunbeds for cosmetic purposes. Scientific Committee on Emerging and Newly Identified Health Risks 2015.

4. Baliarsingh, S.; Behera, P.C.; Jena, J.; Da,s T.; Das,N.B.UVreflectance attributed direct correlation to colour strength and absorbance of natural dyed yarn with respect to mordant use and their potential antimicrobial efficacy.J Clean Prod2015,102, 485-492, https://doi.org/10.1016/j.jclepro.2015.04.112.

5. Hustvedt, D.; Crews, P. C.The ultraviolet protection factor of naturally pigmented cotton, J. Cotton Sci. 2005, 9,47-55.

6. Alebeid, O. K.; Zhao, T.Developing UV protection for cotton fabric.The Journal of The Textile Institute $\mathbf{2 0 1 7}$, 108, 2027-2039,https://doi.org/10.1080/00405000.2017.1311201. 
7. Ghosh, K.; Khandual, A. ; Sahoo, B.Developing Eco-friendly UV protective textiles based on plant extract. Journal of Emerging Technologies and Innovative Research 2018, 5, 461-467, (ISSN-2349-5162).

8. Mallik, S.K.; Arora, T.UV radiations: problems and remedies.Man Made Text. India2003, 46, 164-169.

9. El-Zaher, N. A.; Kishk, S. S. Study of the effect of UVR on the chemical structure, mechanical properties and crystallinity of nylon-6 films. Colorage 1996, 43, 25-30.

10. Perenich, T.A. Textiles as preventive measures for skin cancer. Colorage 1998, 45, 71-73.

11. Wong, W.; Lam, J.K..; Kan, C.; Postle, R. Influence of reactive dyes on ultraviolet protection of cotton knitted fabrics with different fabric constructions. Textile Res. J 2015, 86, 512-532, https://doi.org/10.1177/0040517515591776.

12. Slater, K. Protection of or by textiles from environmental damage. In EnvironmentalImpact of Textiles: Production, Processes and Protection. Woodhead Publishing, Cambridge, Eng. 2003.

13. Rosu, D. C.; Cristian, D. V.Effect of Ultraviolet light on the properties of dyed cotton cellulose. Annals of the university of Oradea fascicle of textiles -leather work 2016, 123-126.

14. Nusheng, C.; Cheng, K. L.; Eleanor, M. B.; Nicholas, L.Environment-friendly treatment to reduce photoyellowing and improve UV-blocking of wool. Polymer degradation and stability 2020, 181, 109319, https://doi.org/10.1016/j.polymerdegradatab.2020.109319.

15. Nazmul, K.; Shaila, A.; Kate, L.; Laura, C.O.; Daria, V.A.; Chris, C.; Andrew, D.F.;Il-Doo K.; Kostya S.N.Sustainable Personal Protective Clothing for Healthcare Applications: A Review. ACS Nano 2020,14, 10, 12313-12340, https://doi.org/10.1021/acsnano.0c05537.

16. Kostajnšek, K.; Dimitrovski, K. Use of Extended Cover Factor Theory in UV Protection of Woven Fabric.Polymers 2021, 13, 1188, https://doi.org/10.3390/polym13081188.

17. Rosinskaya, C.; Djam, M.; Weiberg, A.; Kizil, Z. Improvement of UV protection of cotton fabrics dyed with binary mixtures of the reactive dyes. Melliand Int. 2003, 9,147-148.

18. Mohammad G.; Ehsan G. Investigation into the UV-Protection of Woven Fabrics Composed of Metallic Weft Yarns. AUTEX Research Journal 2015, 1,1-6, https://doi.org/10.1515/aut-2015-0021.

19. Aguilera, J.; De Galvez, M.V.; Sanchez, R.C; Herrera, C.E. New Advances in Protection against Solar Ultraviolet Radiation in Textiles for Summer Clothing. Photochemistry and Photobiology 2014, 90, 11991206, https://doi.org/10.1111/php.12292.

20. Kamal, M.S.; Mahmoud, E.; Hassabo, A.G.; Eid, M.M. Effect of some construction factors of bi-layer knitted fabrics produced for sports wear on resisting ultraviolet radiation. Egy. J. Chem. 2020, 63, 4369 - 4378 , https://doi.org/10.21608/ejchem.2020.25922.2514.

21. Campos,D.A.; Narciso, D.D.; Cortijo, L.J.Textiles Functionalized with ZnO Nanoparticles Obtained by Chemical and Green Synthesis Protocols: Evaluation of the Type of Textile and Resistance to UV Radiation.Fibers, 2021, 9, 10, https://doi.org/10.3390/fib9020010.

22. Achwal, W.B. Sun protection properties of textile substrates. Colorage 1997,44, 31-32.

23. Djam, M.; Rosinskaja, C.; Kizil, Z.; Weinberg, A. Assessment method for UV protective properties of textiles. Melliand Int. 2001, 7, 144-146.

24. Grifoni D.; Bacci L.; Zipoli G.; Carreras G.; Baronti S.; Sabatini F. Laboratory and Outdoor Assessment of UV Protection Offered by Flax and Hemp Fabrics Dyed with Natural Dyes. Photochemistry and Photobiology 2009, 85, 313-320.

25. Louris E.; Sfiroera E.; Priniotakis G.; Makris R.; Siemos H.; Efthymiou C.; Assimakopoulos M N. Evaluating the ultraviolet protection factor (UPF) of various knit fabric structures, Aegean International Textile and Advanced Engineering Conference (AITAE 2018).IOP Conf. Series: Materials Science and Engineering 2019, 459, 012051, https://doi.org/10.1088/1757-899X/459/1/01205.

26. Porga, D.; Jana, S.; Galhot, M.. Functional properties of natural dyed Textiles. Intechopen, London, UK 2020, https://doi.org/10.5772/intechopen.88933.

27. Standards Association of Australia, Standard AS/NZS 4399, sun protective clothing, evaluation and classification, Homebush Australian/Newzealand Standard 2017.

28. American Society for Testing Materials (ASTM) International Standard D6603-19, Standard guide for labeling of UV-protective textiles 2019, https://doi.org/10.1520/D6603-00.

29. O'Quinn, R.P.; Wagner, R.F. Unusual patterns of chronic photodamage through clothing. Cutis 1998, 61, $269-71$.

30. Menter, J.M.; Hollins, T.D.; Sayre, R.M.; Etemad, A.A.; Wliils, I.; Hughes, S.N. Protection against photodynamic therapy (PDT)-induced photosensitivity by fabric material.Photodermatol Photoimmunol Photomed 1998, 4, 154-159, https://doi.org/10.1111/j.1600-0781.1998.tb00034.x. 
31. Baschong, W.; Artmann, C.; Schaumann, M.Sun protection beyond sunburn-UV-protection in nonCaucasians. The American Academy of Dermatology $62^{\text {nd }}$ Annual Meeting, Washington DC (February 6-11) 2004.

32. Wang,S.Q.; Lim, H.W. Principles and Practice of photoprotection, Springer International publishing Swizerland 2016, https://doi.org/10.1007/978-3-319-29382-0.

33. Stankovic, S.; Poparic, G.B.; Popovic, D.; Bizjak, M.Ultraviolet Protection Factor of Gray-state Plain Cotton Knitted Fabrics. Textile Research Journal 2009, 79, 1034-1042 ,https://doi.org/10.1177/0040517508102016.

34. Stanford, D.G.; Georgouras, K.E.; Pailthorpe, M.I.Sun protection afforded by a summer weight garment, the effect of wash and wear. Med J. Austr 1995, 162, 422-425.

35. Gayathri, N.; Subrata, D. UV protection finishes and its effects on textiles.Asian Dyer 2018, 15, 47-52.

36. Morton, H.E.; Hearle, J.W.S. Physical properties of textile fibres $4^{\text {th }}$ ed., The Textile Institute, Woodhead publishing limited, Cambridge, England, 2008, 580-583.

37. Asfandyar, K.; Ahsan, N.; Rehman, A.; Maryam, N.; Munir, A.; Kashif, I., Abdul, B.; Shahzad, H.M.A review of UV radiation protection on humans by textiles and clothing. International Journal of Clothing Science and Technology 2020, 32, 869-89, https://doi.org/0.1108/ijcst-10-2019-0153.

38. Farouk, A.; Textor, T.; Schollmeyer, E.; Tarbuk, A.; Grancacic, A.M.Sol-gel-derived inorganic-organic hybrid polymers filled with $\mathrm{ZnO}$ nanoparticles as an ultraviolet protection finish for textiles.AUTEX Research Journal 2010, 10, 58-63.

39. Zuo, D.; Liang, N.; Jing, X.; Dongzhi, C.; Zhang, H.UV protection from cotton fabrics finished with boron and nitrogen co-doped carbon dots. Cellulose 2019, 26, 4205-4212, https://doi.org/10.1007/s10570-01902365-5.

40. Gawish, S.; Helmy, H.; Ramadan, A.N.; Farouk R.; Mashaly, H. M. UV Protection Properties of Cotton, Wool, Silk and Nylon Fabrics Dyed with, Red Onion Peel, Madder and Chamomile Extracts. ,Journal of Textile Science \& Engineering 2016, 6, 1-13, https://doi.org/10.4172/2165-8064.1000266.

41. El-Zaher, N. A.; El-Bassyouni, G. T.; Esawy, M. A.; Guirguis, O. W. Amendments of the Structural and Physical Properties of Cotton Fabrics Dyed with Natural Dye and Treated with Different Mordants. Journal of Natural Fibers 2021, 18,1247-1260, https://doi.org/10.1080/15440478.2019.1689884.

42. Grifoni, D.; Bacci, L.; Di Lonardo S.; Pinelli, P.; Scardigli, A.; et al. UV protective properties of cotton and flax fabrics dyed with multifunctional plant extracts. Dyes Pigments 2014, 105, 89-96.

43. AATCC Test Method 147, "Antibacterial activity Assessment of Textile Material: parallel streak Method" 2016.

44. Tripti, B.; Shahnaz, J. Effect of temperature on the dyeing of cotton fabric with Monascus Purpureus dye. International journal of engineering sciences \&research Technology 2016, 5, 440-443, https://doi.org/10.5281/zenodo.203822.

45. El-Amoudy, E.S.; El-Ebissy, A.A. Optical Studies of Cotton Fabrics Dyed with a Natural Dye.British Journal of Applied Science \& Technology 2015, 9, 159-171, https://doi.org/10.9734/BJAST/2015/17227.

46. Hossain, M.Y.; Sarker, S.; Zakaria, M.; Islam, M.R.; Fayazi, R.U.; Acharjya, S.Influence of Process Parameters on Exhaustion, Fixation and Color Strength in Dyeing of Cellulose Fiber with Reactive Dye. Int J Text Sci Eng, 2020, 3, 127-136, https://doi.org/10.29011/2690-0106.100027.

47. Abdelslam, Sh. H.; Mashaly, H.M.; Abd El-Thalouth, J.I.; Saad, M.O.; Abdel-Azizb, M.S. An Environmental Friendly Approach in Printing of Natural Fabrics on Using Chitosan and Chitosan Nanoparticles. Egypt. J. Chem. 2021, 64, 4283 - 4299, https://doi.org/10.21608/ejchem.2021.63865.3367.

48. Budeanu, R.; Curteza, A.; Radu, C.D. Experimental Researches Regarding the Ecological Dyeing with Natural Extracts. Autex Research Journal 2014, 14, 290-298, https://doi.org/10.2478/aut-2014-003.

49. Ul-Islam S.; Rather, L.J.; Shahid, M.; Khan; M.A.; Mohammad, F. Study the effect of ammonia posttreatment on color characteristics of the annatto-dyed textile substrate using reflectance spectrophotometry. Ind Crops Prod 2014,59,337-342, https://doi.org/10.1016/j.indcrop.2014.05.041.

50. Choudhury, A.K.R. Eco-friendly dyes and dyeing. Advanced Materials and Technologies for Environmental 2018, 2, 145-176. 